\title{
KUALITAS ORGANOLEPTIK DENDENG SAPI YANG DIBERI GULA MERAH DENGAN LEVEL BERBEDA
}

\author{
Febi Febrianingsih ${ }^{1}$, Harapin Hafid ${ }^{2}$ dan Amiluddin Indi $^{2}$ \\ ${ }^{1)}$ Alumnus Fakultas Peternakan Fapet Universitas Halu Oleo \\ ${ }^{2)}$ Dosen Fakultas Peternakan Fapet Universitas Halu Oleo \\ e-mail : harapinhafid@yahoo.co.id
}

\begin{abstract}
Abstrak
Dendeng giling merupakan salah satu produk olahan daging secara tradisional dibuat dari daging giling yang ditambah gula aren dan bumbu-bumbu lainya. Dendeng sudah memasyarakat dan digemari tua-muda sebagai bahan lauk. Penelitian ini bertujuan untuk mengetahui pengaruh penambahan gula aren dengan level yang berbeda terhadap kualitas organoleptik dendeng giling sapi. Materi penelitian dendeng dibuat dari daging sapi bali yang di beri garam, bumbu dan gula merah dengan kosentrasi yang berbeda yaitu $10 \%$, 20\%, dan 30\% dan 40\% sebagai perlakuan. Data diolah dengan analisis sidik ragam berdasarkan Rancangan Acak Lengkap (RAL) dengan 4 perlakuan dengan 15 orang panelis sebagai ulangan. Peubah yang diamati adalah kualitas organoleptik dendeng berupa warna, citarasa, keempukan dan penerimaan umum panelis (akseptabilitas). Hasil menunjukkan bahwa penambahan gula aren pada dendeng giling daging sapi berpengaruh nyata $(\mathrm{p}<0.05)$ terhadap sifat organoleptik yaitu meningkatkan flavor (cita rasa) tetapi menurunkan warna, keempukan. Dan tidak berpengaruh terhadap akseptabilitas dendeng. Disimpulkan bahwa produk olahan dendeng giling daging sapi yang berkualitas baik adalah pada dendeng dengan penambahan gula aren 20\% dimana mempunyai sifat organoleptik yang banyak disukai oleh panelis.
\end{abstract}

Kata kunci: dendeng giling, daging sapi, gula aren

\begin{abstract}
Milled jerked beef is one of the traditional processed meat products, which is made from milled meat and combined with palm sugar and other seasonings. Jerked meat has been socialized and is favorable to the young and adults. This study aims to study the effect of addition different level of palm sugar on the organoleptic quality of milled jerked beef. The jerked beef materials were made from salted Bali beef, seasoning and palm sugar in different concentration, which are 10\%, 20\%, 30\%, and 40\%. Data was analyzed using analysis of variance based on completely randomized design with 4 treatments and 15 panelists as replications. The observed variables were the organoleptic quality of the jerked beef consist of color, taste, softens, and acceptability. The result showed that the addition of palm sugar on the milled jerked beef gave signifficant effect on the organoleptic quality, which were increasing in flavour but decreasing in color and softens. However, the addition of palm sugar did not affect the jerked beef accessibility. In conclusion, better quality of milled jerked beef was founded on jerked beef with $20 \%$ palm sugar addition, which was most of panelist favorite its organoleptic quality..
\end{abstract}

Key Words: milled jerked meat, beef, palm sugar. 


\section{PENDAHULUAN}

Daging merupakan salah satu sumber protein hewani yang tinggi nilai gizinya di bandingkan dengan protein nabati, karena pada daging terdapat asam-asam amino yang lengkap dan seimbang, disamping adanya lemak, mineral dan vitamin yang dibutuhkan tubuh serta mempunyai daya cerna yang tinggi dan mudah diserap. Daging merupakan produk olahan yang mudah rusak, untuk mengatasi hal tersebut dibutuhkan pengolahan menjadi produk lain salah satunya adalah dendeng. Proses pengolahan secara umum dapat mengakibatkan perubahan bentuk yang semula utuh menjadi suatu bentuk lain (perubahan struktur), misalnya perubahan dari daging mentah yang utuh menjadi produk salah satu contohnya adalah dendeng (Abustam, 2000).

Dendeng giling merupakan salah satu produk olahan daging secara tradisional dibuat dari daging giling yang ditambah gula aren, garam dapur serta bumbu-bumbu, kemudian dicetak sebagai lembaran tipis dengan ketebalan kurang lebih $4 \mathrm{~mm}$ dan selanjutnya dikeringkan (Purnomo dan Adiono, 1981). Dendeng yang sudah jadi akan berwarna kecoklat-coklatan karna protein dalam daging akan bereaksi dalam gula merah dalam bumbu. Gula aren adalah salah satu jenis produk pangan yang dikenal secara internasional yang selama ini merupakan produk tradisional Indonesia. Selain digemari sebagai bahan pelengkap dalam konsumsi makanan sehari-hari (Novianti dan Suharto, 2009). Penambahan gula aren pada dendeng berfungsi memodifikasi rasa, memperbaiki aroma, warna dan tekstur produk (Soeparno,2009).

$$
\text { Berdasarkan latar belakang }
$$
tersebut, maka dilakukan penelitian tentang Pengaruh pemberian gula aren pada level yang berbeda terhadap kualitas organoleptik dendeng sapi. Penelitian ini bertujuan untuk mengamati warna, cita rasa, keempukan dan akseptabilitas dendeng sapi.

\section{MATERI DAN METODE}

Penelitian ini telah dilaksanakan pada tanggal 2 - 4 Januari 2016, bertempat di Laboratorium Produksi Ternak Fakultas Peternakan Universitas Halo Oleo, Kendari.

Peralatan yang digunakan dalam penelitian ini adalah mesin penggiling kasar, food processor, pisau, telenan, timbangan analitik, saringan, baskom/wadah, cetakan logam, oven, wajan, spatula, tissue, dan kertas label.

Bahan penelitian ini adalah daging sapi Bali Bagian Topsidepada paha sebanyak $2 \mathrm{~kg}$ yang diperoleh dari rumah potong hewan (RPH) Kota kendari, gula aren, ketumbar, bawang putih, bawang merah, lengkuas, garam, merica, minyak goreng, didapat dari pasar sentral Kendari.

Prosedur penelitian yang dilakukan yaitu persiapan daging sapi segar, penimbangan bahan, penggilingan dan pencampuran bahan, pencetakan dendeng $4 \mathrm{~mm}$, pengeringan/pengovenan, dan penggorengan.

Metode yang digunakan adalah rancangan acak lengkap (RAL) dengan menggunakan 4 perlakuan dengan 15 orang panelis sebagai ulangan yaitu $10 \%, 20 \%, 30 \%, 40 \%$.

Parameter yang di amati yaitu warna, cita rasa, keempukan, akseptabilitas (penerimaan panelis). Skor penilaian skala hedonik untuk uji kualitas dendeng sapi disajikan pada Tabel 1. 
Tabel 1. Skor Penilaian Skala Hedonik untuk Uji Kualitas Dendeng Sapi

\begin{tabular}{|c|c|c|}
\hline $\begin{array}{l}\text { Peubah (parameter) } \\
\text { (variable) }\end{array}$ & $\begin{array}{l}\text { Skala Hedonik } \\
\text { (Hedonic scala) }\end{array}$ & $\begin{array}{l}\text { kriteria dendeng } \\
\text { (Criteria dendeng) }\end{array}$ \\
\hline \multirow[t]{5}{*}{ Warna (Color) } & 1 & Coklat kehitaman (blackish brown) \\
\hline & 2 & $\begin{array}{l}\text { Agak coklat kehitaman (somewhat } \\
\text { blackish brown) }\end{array}$ \\
\hline & 3 & Coklat (brown) \\
\hline & 4 & Agak coklat (slightly brown) \\
\hline & 5 & Tidak coklat/pucat( not brown/pale) \\
\hline \multirow[t]{5}{*}{ Cita Rasa (Flavor) } & 1 & $\begin{array}{l}\text { Kuat Aroma Daging (heavy duty flesh } \\
\text { aroma) }\end{array}$ \\
\hline & 2 & $\begin{array}{l}\text { Agak Kuat Aroma Daging (rather flesh } \\
\text { aroma strength) }\end{array}$ \\
\hline & 3 & $\begin{array}{l}\text { Sedikit Lemah Aroma daging (little bit } \\
\text { flesh aroma frail) }\end{array}$ \\
\hline & 4 & $\begin{array}{l}\text { Agak Lemah Aroma daging (rather flesh } \\
\text { aroma frail) }\end{array}$ \\
\hline & 5 & $\begin{array}{l}\text { Lemah Aroma Daging (namby pamby } \\
\text { flesh aroma) }\end{array}$ \\
\hline \multirow[t]{5}{*}{ Keempukan } & 1 & Sangat Empuk (extremely tender) \\
\hline & 2 & Empuk (slightly tender) \\
\hline & 3 & $\begin{array}{l}\text { Keempukan sedang (neither tough or } \\
\text { tender) }\end{array}$ \\
\hline & 4 & Alot (slightly tough $)$ \\
\hline & 5 & Sangat Alot (extremely tough) \\
\hline \multirow[t]{5}{*}{ Akseptabilitas } & 1 & Sangat disukai (likeextremely) \\
\hline & 2 & Disukai (like a little) \\
\hline & 3 & Cukup disukai (neither like or dislike) \\
\hline & 4 & Tidak disukai (dislike a little) \\
\hline & 5 & Sangat tidak disukai (dislike extremely) \\
\hline
\end{tabular}

Sumber :Hafid (2000); Hafid \& Syam (2007); Hafid et al. (2014)

\section{Analisis Data}

Data diolah dengan analisis sidik ragam berdasarkan Rancangan Acak Lengkap (RAL) dengan 4 perlakuan dengan 15 orang panelis sebagai ulangan. Apabila terdapat pengaruh perlakuan maka akan dilakukan uji lanjut dengan uji beda nyata terkecil (BNT) sesuai petunjuk Gazperz (1991).

\section{A. Warna Dendeng Giling Daging Sapi}

Tabel 2. menunjukkan bahwa tingkat penambahan gula aren berpengaruh sangat nyata $(\mathrm{P}<0,01)$ terhadap warna dendeng giling daging sapi. Hasil uji beda nyata terkecil (BNT) menunjukkan bahwa adanya perbedaan nyata $(\mathrm{P}<0,01)$ antara tingkat penambahan gula aren $(10 \%, 20 \%, 30 \%$ dan 40\%). Hal ini berarti bahwa dendeng giling dengan tingkat penambahan gula aren $20 \%$ menghasilkan warna dendeng giling coklat kehitaman dibandingkan dengan tingkat penambahan gula aren30 dan $40 \%$.

Hal tersebut bisa terjadi karena adanya reaksi millard yang terjadi yaitu gugus karbonil dari gula reduksi bereaksi dengan gugus amino dari 
Tabel 2. Nilai Rataan Skor Hedonik Dendeng Giling Sapi Berdasarkan Level Gula aren yang Berbeda

\begin{tabular}{llcccc}
\hline \multirow{2}{*}{ Peubah } & & \multicolumn{3}{c}{ Persentase Gula Aren Dendeng Sapi } \\
\cline { 3 - 6 } & & $\mathbf{A}(\mathbf{1 0 \%})$ & $\mathbf{B}(\mathbf{2 0 \%})$ & $\mathbf{C}(\mathbf{3 0 \%})$ & $\mathbf{D}(\mathbf{4 0 \%})$ \\
\hline \multirow{2}{*}{ Warna } & Rata-rata & $3.40^{\mathrm{a}}$ & $2.20^{\mathrm{b}}$ & $2.40^{\mathrm{b}}$ & $2.40^{\mathrm{b}}$ \\
& S. Deviasi & 0.55 & 1.30 & 1.14 & 0.89 \\
\hline Cita rasa & Rata-rata & $1.93^{\mathrm{a}}$ & $2.67^{\mathrm{ab}}$ & $2.73^{\mathrm{b}}$ & $3.13^{\mathrm{ab}}$ \\
& S. Deviasi & 0.70 & 0.82 & 1.22 & 1.36 \\
\hline Keempukan & Rata-rata & $3.13^{\mathrm{a}}$ & $1.93^{\mathrm{b}}$ & $2.27^{\mathrm{b}}$ & $2.20^{\mathrm{b}}$ \\
& S. Deviasi & 0.92 & 0.88 & 0.80 & 0.77 \\
\hline Akseptabilitas & Rata-rata & 2.27 & 2.40 & 2.07 & 2.07 \\
& S. Deviasi & 0.70 & 0.83 & 0.70 & 0.88 \\
\hline
\end{tabular}

Ket: superskrip yang berbeda pada peubah yang sama menunjukkan perbedaan nyata $(p<0,05)$

protein daging dan asam-asam amino secara non enzimatik, dan hasil reaksinya menimbulkan warna coklat gelap terhadap panas sehingga mengakibatkan warna dendeng menjadi coklat kehitaman. Semakin tinggi tingkat penambahan gula aren warna pada dendeng giling akan semakin gelap karena akibat dari proses pembuatan yang menggunakan gula merah dan saat penggorengan terjadi reaksi panas terhadap gula sehingga mengakibatkan warna dendeng menjadi gelap (coklat kehitaman).

Hal ini mendukung pernyataan yang dikemukakan oleh Nursiam (2010) bahwa warna gelap yang terjadi pada dendeng diakibatkan oleh adanya reaksi antara gula terhadap panas pada saat dilakukan penggorengan. Hal tersebut bisa terjadi juga karena terjadinya reaksi millard yaitu gugus karbonil dari gula reduksi bereaksi dengan gugus amino dari protein daging dan asam-asam amino secara non enzimatik, dan hasil reaksinya menimbulkan warna coklat gelap.

\section{B. Flavor (Cita Rasa) Dendeng Giling Daging Sapi}

Flavor/cita rasa adalah sensasi yang kompleks, melibatkan bau dan rasa/taste, tekstur, suhu dan $\mathrm{pH}$ dari semua ini, bau adalah yang paling penting. Evaluasi bau dan rasa sangat tergantung pada panel cita rasa (Lawrie, 1995). Nilai rata-rata hasil pengujian tingkat penambahan gula aren pada level yang berbeda terhadap cita rasa dapat dilihat pada Tabel 2

Hasil penelitian seperti terlihat pada Tabel. 2 menunjukan bahwa tingkat penambahan gula aren berpengaruh sangat nyata $(\mathrm{P}<0,01)$ terhadap flavor dendeng giling daging sapi. Hasil uji beda nyata terkecil (BNT) menunjukkan bahwa terdapat perbedaan sangat nyata $(\mathrm{P}<0,01)$ pada penambahan gula aren (10\%, 20\%, 30\%dan 40\%).

Hal ini berarti bahwa dendeng giling dengan penambahan gula aren $10 \%$ memiliki rasa yang kuat aroma daging. Semakin tinggi tingkat penambahan gula aren maka flavor yang dihasilkan akan semakin lemah aroma dagingnya. Hal ini dikarenakan tingginya tingkat penambahan gula aren sehingga dapat merubah cita rasa/flavor dendeng. Hal ini mendukung pendapat Ferial (2010) dan Mardiana (2011) bahwa semakin tinggi taraf gula aren yang ditambahkan pada dendeng maka akan semakin terasa lemah aroma daging, sebaliknya semakin rendah taraf 
gula aren maka semakin terasa kuat aroma daging.

\section{Keempukan Dendeng Giling Daging Sapi}

Keempukan merupakan faktor utama dalam penilaian daging yang mempengaruhi selera konsumen. Nilai rata-rata hasil tingkat penambahangula aren pada level yang berbeda terhadap keempukan dapat dilihat pada Tabel 2.

Hasil penelitian seperti terlihat pada Tabel 2 menunjukan bahwa bahwa tingkat penambahan gula aren berpengaruh sangat nyata $(\mathrm{P}<0,01)$ terhadap keempukan dendeng giling daging sapi. Hasil uji beda nyata terkecil (BNT) menunjukkan bahwa adanya perbedaan sangat nyata $(\mathrm{P}<0,01)$ terhadap tingkat penambahan gula aren $(10 \%, 20 \%, 30 \%$ dan $40 \%)$.

Hal ini menunjukkan bahwa dendeng giling dengan penambahan gula aren $20 \%$ yang berarti sangat empuk dibandingkan tingkat penambahan gula aren $10 \%, 30 \%$ dan $40 \%$. Hal ini berarti dendeng giling dengan tingkat penambahan gula aren20\% mengkasilkan nilai rata-rata keempukan yang lebih baik. Hal ini dikarenakan tingkat penambahan gula aren yang sedang atau stabil, sehingga dapat mengempukkan dendeng giling. Hal ini mendukung pendapat Ferial (2010) dan Mardiana (2011) bahwa semakin tinggi gula aren yang ditambahkan pada dendeng maka akan semakin empuk dendeng, sebaliknya semakin rendah gula aren maka semakin alot dendeng giling.

\section{Akseptabilitas Dendeng Giling Daging Sapi}

Akseptabilitas yaitu penerimaan panelis atau kesukaan. Penilaian kesukaan untuk melihat respon panelis terhadap produk yang dihasilkan. Nilai rata-rata hasil pengujian tingkat penambahan gula aren pada level yang berbeda terhadap kesukaan dendeng giling dapat dilihat pada Tabel 2.

Tabel. 2 menunjukan bahwa tingkat penambahan gula aren tidak berbeda nyata $(\mathrm{P}<0,05) \quad$ terhadap kesukaan dendeng giling. Hal ini signifikan sehingga tidak perlu uji lanjut dan menunjukkan bahwa dendeng giling dengan penambahan gula aren 30 dan $40 \%$ mencapai nilai yang baik dan sangat disukai.

Hal ini disebabkan karena gula aren yang memiliki rasa dan aroma yang khas yang sangat disukai oleh konsumen karena gula aren banyak memiliki manfaat dan kegunaan bagi mahluk hidup. Hal ini mendukung pernyataan Ferial (2010) dalam Mardiana (2011) bahwa hal tersebut disebabkan karena gula aren memiliki rasa dan aroma yang sangat disukai oleh konsumen, selain itu gula juga sering digunakan sebagai bumbu masakan karena rasanya yang khas.

\section{KESIMPULAN DAN SARAN}

\section{A. Kesimpulan}

Berdasarkan hasil dan pembahasan dapat disimpulkan bahwa penambahan gula aren pada dendeng giling daging sapi berpengaruh nyata $(p<0,05)$ terhadap sifat organoleptik dendeng sapi yaitu meningkatkan flavor (cita rasa) tetapi menurunkan warna, keempukan. Namun tidak berpengaruh nyata $(p>0,05)$ terhadap akseptabilitas dendeng.

\section{B. Saran}

Untuk menghasilkan produk olahan dendeng giling daging sapi yang berkualitas baik, sebaiknya menggunakan penambahan gula aren $20 \%$ karena flavor (cita rasa) yang banyak di sukai oleh konsumen. 
DAFTAR PUSTAKA

Abustam, E., 2000. Pengolahan Dan Pengawetan Daging. Fakultas Peternakan Universitas Hasanuddin. Makassar.

Ferial. A. 2010. Pengaruh lama pengeringan dan level penambahan nanas (Ananas comosus) terhadap kualitas dendeng giling daging sapi. Fakultas Peternakan Universitas Hasanuddin. Makassar.

Gasperz, V., 1991. Metode Rancangan Percobaan. Penerbit CV. Armico. Bandung.

Hafid, H., Nuraini dan Syam, A. 2000. Kualitas daging kambing lokal dengan metode pelayuan dan pemasakan serta umur yang berbeda. Laporan Penelitian. Fakultas Pertanian. Universitas Haluoleo. Kendari.

Hafid, H. dan Syam, A. 2007. Pengaruh aging dan lokasi otot terhadap kualitas organoleptik daging sapi. Buletin Peternakan. 31(4) : 209-216.

Hafid, H., Nuraini dan Inderawati. 2014. Sifat organoleptik daging itik afkir yang diberi perlakuan stimulasi listrik. Prosiding seminar nasional dan workshop optimalisasi sumber daya local pada peternakan rakyat sebagai teknologi.Fakultas

Peternakan. Universitas Hasanuddin. Makassar. Hal 182-193.
Lawrie, R.A. 1995. Ilmu Daging. Terjemahan : A. Parakkasi. Universitas Indonesia Press, Jakarta.

Mardiana. 2011. Pengaruh ketebalan yang berbeda dan tingkat penambahan nanas (Ananas comosus) terhadap kualitas dendeng giling daging sapi. Fakultas Peternakan Universitas Hasanuddin. Makassar.

Novianti, J. dan Suharto. 2009. Perancangan dan uji coba alat evaporator nira aren. Laporan Penelitian LPPM. Jurusan Teknik Kimia, Fakultas Teknologi Industri, Universitas Katolik Parahyangan. Bandung.

Nursiam, I. 2010. Pembuatan Dendeng Daging Sapi. Intannursiam's blog. Diakses Januari 2016.

Purnomo, H dan Adiono. 1984. Ilmu Pangan. NUFFIC. Universitas Brawijaya. Malang.

Soeparno. 2009. Ilmu dan Teknologi Daging. Cetakan ke lima. Gajah Mada University Press. Yogyakarta. 